\title{
The work of the mind for spiritual fulfillment in Orthodox patristics
}

\author{
PhD. Paul SCARLAT \\ Valahia University of Târgovişte, \\ ROMANIA, \\ E-mail: p.scalrlat@libero.it
}

\begin{abstract}
The mysticism of the Orthodox Church provides spiritual fulfillment of man in three stages: purification, enlightenment or knowledge, and perfection or union with God. Purification is the removal of passions and their replacement with virtues. For example, the philokalic texts, which are a collection of texts written by 25 Holy Fathers, form a true handbook containing various themes, but all of them educate on "the love of divine beauty" or "the love of virtue", as the etymology of the chosen title for the compilation. Of these, the study of the mind and its dynamics is a predilection for most authors, some of whom have offered real treatises on this subject. This study limits the presentation of some Church Fathers who have spoken of this argument. The mind is a place where good and evil thought stake on a continuous struggle that positively or negatively influences human behaviour and closeness to God. For this reason, man's special attention is needed on the mind, that is, a permanent nepsis.
\end{abstract}

Keywords: Philokalia; Orthodox; Nepsis, Mind; Vigilance; Heart; Self;

\section{INTRODUCTION}

In the context in which religiosity becomes more subjective and people seek to fill spiritual needs away from church institutions, the present study aims to briefly review a representative part of oriental Christian mysticism - the battle against thoughts, for a better understanding of the phenomenon. It is positive that many books of Orthodox spirituality are published today, and it is admirable to reactivate the work of the Holy Fathers, but without spiritual guidance, which is obligatory in Orthodoxy ${ }^{1}$, the texts may lead to unwanted or even contrary effects to the intentions of the authors. This caution was rightly given:

\footnotetext{
„Vigilance is understood as a type of defensive barrier to the preservation of purity in action and being, reached by the Christian in relation to the world. Often confused with caution, it is likely to be taken as a mechanism that generates suspicion and fear, and which favors a negative aspect and a prejudice towards the whole reality that wrongly or rightly can infect the identity of the believer" ${ }^{2}$.
}

\footnotetext{
${ }^{1}$ Hausherr, Irénée, Paternitatea şi îndrumarea duhovnicească în Răsăritul creştin, Sibiu, Deisi 1999.

2 Piovano, Adalberto, Vigilanza e attenzione su di sé: il versante monastico, Tredimensioni 4(2007) 275-282, p.275.
} 
For this reason, it is necessary to emphasize from the beginning that the work of the mind in the Orthodox tradition is an action that concerns the entire human person through his life. Recently, Saint Paisios of Mount Athos said that:

\begin{abstract}
„,when there is spiritual nobility, self-sacrifice, man is related to God, is in touch with Him, and his mind is continually upon Him. Then, even if he does not pray, he still prays. His whole life is prayer. He does not think of anything else; whatever he does, his mind is continually there, with God" 3 .
\end{abstract}

The interest in this theme is both theological and anthropological. Thought disputes and spiritual achievement directly affect man's way of life. Sandu Tudor, the initiator of a movement of spiritual resilience and awakening in Romania in the middle of the 20th century, said that :

\begin{abstract}
"we ourselves create our unhappiness and suffering through our own dark minds of evil sins and thoughts. We are stressed, worried, angry, emotional, troubled, restless, insecure, feeling inadequate, pessimistic, malicious, disconnected, and because of sins and the war caused by the evil thoughts, we do not rejoice in all our successes and accomplishments, more quickly than our failures and failures of peers" 4 .
\end{abstract}

\title{
1. Rediscovering the self in the heart by awakening and attention
}

The idea of the awakening mind comes in Christianity from the writings of the New Testament. "Watch your life and doctrine closely" (Timothy 4:16), "be ready, that at the time when you do not think the Son of Man will come" (Luke 12: 40), "Watch and pray that you do not enter into temptation" (Matthew 14,38) are passages that invite believers to a greater mindfulness, a research of what is happening around or in mind. The word used Nipsis, which comes from the Greek language, means this state of attention to the dynamics of the mind and the constant care for cultivating the spirit. Awakening is a state of mind of waking (compared to the state of man when he does not sleep, the state of vigilance), a state of attention and remembering of the mind the movements of the soul and thoughts.

When he interprets the words of the gospel „Watch your life and doctrine closely”, Saint Basil the Great says,:

\begin{abstract}
we men, we fall into sin lightly with the thought. Therefore, He who built our hearts one by one, knowing that most sins are committed by the impulse of our thoughts, commanded that the mind be clean first. And because we sin easily with the mind, God asks us to take more care and caution. That as the foreseeable doctors strengthen long before, by prophylactic means, the weaker parts of the bodies, so also the Carrier, and the true Doctor of the Souls, provided with a stronger guard especially the part of our soul that we know More inclined to $\sin " 5$.
\end{abstract}

So, if man was endowed with a superior mind above all creatures, by which he is just like God, this capacity is the place where thoughts can be good or bad, virtuous or sinful. The mind is a gift from God that man is indebted to keep.

It is very important for the attention to go inwards, leaving aside the general judgments of the world. In a famous dictum that is found in the Egyptian Apophthegm Patrum, Anthony the Great asks answers to his judgments from God, but receives a response that demands a major, if not exclusive, attention on the self:

\footnotetext{
${ }^{3}$ Paisie Aghioritul, Cuvinte duhovnicești. Vol IV. Despre rugăciune, București, Evanghelismos 2013, p.168.

${ }^{4}$ Daniel de la Rarău, Gândurile bune în viaţa creştinului ortodox. Viaţa ca o prăznuire duhovnicească. Colecția „Rugul Aprins”, Panaghia 2013, p. 7.

${ }^{5}$ Vasile cel Mare, Scrieri. Omilia a III-a la cuvintele: Ia aminte de tine insuti. Părinți și Scriitori Bisericești. Vol. 17, București, EIBMBOR, 1986, p. 366.
} 
"Lord, why do some who live a little, die, and others get so old? And why are some poor and rich? How are the unrighteous enriched, and the righteous poor? And a voice came to him, saying: Anthony, remember that you are judged by God, and it is not good for you to know" 6 .

Special attention given by the Holy Fathers to minds is due to the fact that it is a human organ capable of controlling their body activities. As such there is a close link between mind and behaviour, and the former is largely responsible for sinful actions. John of Damascus $^{7}$ says that noerón, meaning the mind, is an organ with which God has endowed man to think and decide before committing any act. Maximus the Confessor advises in this sense in the Second Hundred Texts on Love: "Do not use evilly the ideas, lest you be forced to use evil actions. For if anyone does not sin first with the mind, he will not sin either with the action" $"$.

This reduction of physical life to the inner struggle of thoughts is a constant in the writings of the Holy Fathers. Macarius of Egypt, also known as Macarius the Elder, says that it is necessary an exclusive concentration of forces on thoughts to succeed in the spiritual ascesis: "it is therefore right that all man's struggle shall be undertaken with regard to the mind" 9 . The attentions of the self that the Holy Fathers speak of are of many kinds, as we find it treated in the work of Simeon the New Theologian. Thus, there is a focus on speech by which the monk takes care of the words spoken in prayer:

\begin{abstract}
"When one says this prayer, he raises his hands and eyes together with his mind in heaven, and the mind forms divine meanings and imagines his heavenly beauties, the hierarchies of Angels and tents of the righteous and, simply speaking, everything he heard from the Scriptures gathers them in mind at the time of prayer; He is stirring up his soul to divine love, looking at heaven and sometimes shedding tears in his eyes" 10 .
\end{abstract}

It is an urge to participate with the mind through the body language, which is, in my opinion, very real nowadays ${ }^{11}$. For prayer to be fruitful, a conscious return is needed on prayers and liturgical texts. It is very important to emphasize that the attention to repetitive prayer in Orthodox monasticism does not stem from an incessant begging of Christ, but from man's anthropological need to form mental habits:

\footnotetext{
"we repeat many times the pre-eternal Name of Christ, not because Christ does not hear the first time we call Him, but that our mind may unite with Him, for Christ is all for us, and we will end in Him" 12 .
}

The second attention is contemplative, in the sense that the mind is no longer confined to the body's observation and begins to focus on what is useful to salvation. It chooses itself, without the need for external stimuli:

\footnotetext{
${ }^{6}$ Antonie cel Mare, Patericul Egiptean, Alba Iulia, Reîntregirea 2003, p. 10.

${ }^{7}$ Ioan Damaschinul, Dogmatica, Bucureşti, Apolgeticum 2004, p. 59.

${ }^{8}$ Maxim Mărturisitorul, Filocalia. Vol II, Apologeticum, p.107; "Sinning, not blaming the deed but the thought. For if the mind did not take it before, it would not have followed the body", Marcu Ascetul, Filocalia. Vol. I, Sibiu, Editura Institutul de Arte Grafice „Dacia Traiană” 1947, p. 241.

${ }^{9}$ Macarie Egipteanul, Cele cincizeci de omilii duhovnicești. Părinți și Scriitori Bisericești. Vol. 34, București, EIBMBOR 1992, p. 122.

${ }^{10}$ Simeon Noul Teolog, Metoda sfintei rugăciuni şi atențiuni. Filocalia. Vol. 8, București, EIBMBOR 1979, p. p. 529.

${ }^{11}$ But there are also different views that accept prayers without mind participation: "The prayer of Jesus only with his mouth, without participating in the mind also helps. Of course, it does not drive the enemy out, but with the breaths you take, immobilize him where he is”, Paisie Aghioritul, Cuvinte duhovnicești, p. 154.

${ }^{12}$ Paisie Aghioritul, Cuvinte duhovnicești, p. 153.
} 
"the mind is withdrawing from the senses, protecting its senses from the outside, and gathering all its thoughts, so that it will not go after the empty things; then researching its thoughts, remembering requests that speak to God with the mouth, or bring forth the robbed thoughts (of the devil), so she embraces itself in passion, starts to return to itself with force" 13 .

The third form of attention, also called mystic, is "attention of the heart" or the discovery of the light that springs from the heart:

"At first you will find a darkness and an unfathomable thickness. But by persevering and doing this day and night, you will find, a miracle, endless joy. For as soon as the mind finds the place of the heart, it sees what it does not believe. It sees the air that is in the middle of its heart, and sees itself entirely bright and full of distinctive power. And so forth, as soon as one thinks a thought, before it is formed and takes shape, it is moved by the call of Jesus Christ and consumes it" ${ }^{14}$.

The recovering the self is the discovery of the heart, a similarity in patristic terminology that identifies the two notions in two comments. Dumitru Stăniloaie sees two meanings of the heart that the Fathers use in relation to the mind. On the one hand, the heart is the hidden centre of the mind, its depth, which lies at the heart of cognitive abilities, or where the attraction for beauty and God is born. On the other hand, the heart also means the subconscious of the passions, where affections guide existence wholly or the superconscious where the impulse of the faith lies:

\begin{abstract}
"the memory of our vibrations and passionate actions, imprinted in our being, related to its biological nature, as the super-conscious would be the memory of spiritualized acts and the potency of higher energies. They are also called one heart because they are hidden, central regions of our being, one of the spirit, the other of the soul's life linked to the biological side" ${ }^{15}$.
\end{abstract}

Hence, the uniqueness of the human mind is closely linked to the believer's voluntary act. Man has a reason, but is obliged to use creation (including his own) through the will. In fact, the unity of the reasoning of thoughts and the action of man to control his thoughts stems from the theological anthropology of the image of God that he receives in creation ${ }^{16}$. Thus, the Holy Fathers see this "in the image" of God, reason ${ }^{17}$, self-will and free will ${ }^{18}$, or reason and free will together ${ }^{19}$. That is why it can be said that the mind is not the place in

\footnotetext{
${ }^{13}$ Simeon Noul Teolog, Metoda sfintei rugăciuni şi atențiuni. Filocalia. Vol. 8, București, EIBMBOR 1979, p. 530-531.

${ }^{14}$ Simeon Noul Teolog, Metoda sfintei rugăciuni, p. 536-537.

${ }^{15}$ Stăniloaie, Dumitru, Ascetica și mistica Bisericii Ortodoxe, București, EIBMBOR 2002, p. 172-173.

16 "When the mind will unite with God, then man will think of nothing else, not only of God. Thus, the mind of man passes from one face to another, and is created in its likeness. Because something else is gone. The mind is good, but it is on another frequency", Paisie Aghioritul, Cuvinte duhovnicești, p. 169.

${ }_{17}$ Atanasie cel Mare, Cuvânt împotriva elinilor, Tratat despre întruparea Cuvântului, Trei cuvinte împotriva arienilor, București, IBMBOR 2010, p. 142; "the mind of man is a good thing, and through it we are the image of the Creator ... but if reason is directed to the divine things and receives in itself from the Gifts of the Spirit, then it comes to understand the divine truths as the powers of the flesh allow it", Vasile cel Mare, Epistola 233. Părinți și Scriitori Bisericești. Vol. 12, București, EIBMBOR 1988, p. 480.

18 "One by rational nature has as a natural power rational desire, which is also called the will of the rational soul, through which we will reason and in reasoning, we are going towards something deliberate willingly. So, we will, seek, think, deliberate, and judge, develop a mood, choose and start on what we have chosen and is useful”, Maxim Mărturisitorul, Disputa Sfântului Maxim cu Pyrhus. Părinți și Scriitori Bisericești. Vol. 81, București, EIBMBOR 1990, p. 324.

19 "Who among the heavens is said to be the image of the God the highest? Does the Sun have the image of the Maker in it? But the moon, but the other stars? All are inanimate and material. They have only bright bodies in
} 
which man is passionately accepting thoughts, but is the space in which man is indebted to labor, to construct thought by properly arranging the ideas and representations that are born.

The noetic and intellectual abilities that make it different from the rest of creation are also a way of special communication with God. The mind (nous) is a window or gate to the soul. Reason is an eye of the soul, which in the Eastern Christian tradition is also called the heart, that is, the spiritual centre of man. The Orthodox Asceticism is a "transition from multiplicity to unity" ${ }^{20}$, from the diversity of senses to spiritual poverty, from the richness of perceptions to the unique taste of God. That is why the purpose of the world's heart, the retreat from within the world, is the attainment of a gradual silence in which the mind is emptied of any visual, conceptual or fantastic image to contemplate. The final victory of the mind in the struggle with evil thoughts is the ability to anchor and contemplate God.

\section{Thoughts lead to falling into sin}

The term used by the Holy Fathers to appoint the intellectual product, the thinking faculty is logismos ${ }^{21}$. There are two kinds of thoughts produced by discursive reason: some that are an obstacle to God's knowledge, coming from the passions of men and others that fall under the paternity of virtues. Some are clean and others unclean ${ }^{22}$.

The mind is in permanent motion. It perceives the environment through the senses, has a consciousness of things, and when it is lacking, it is capable of building images by itself. The human imagination often replaces the lack of perception by constructing what the Holy Fathers call incantations or phantasms: "Most people do not know that all thoughts are nothing more than mere enlightenments of sensible and worldly things" ${ }^{23}$. So, between thoughts and reasoning, the mind is an organ that invents new mental images with which the individual must confront oneself. Whoever looks behind these ghosts will discover the bad thoughts ${ }^{24}$.

When interpreting the definition of the term of logismos by the Holy Fathers, Tomás Špidlík notes that this is not a thought as we understand it, but rather translates the concept of image of the mind ${ }^{25}$. It is more a fantasy that is borne on the external or inferior part of the cognitive faculty, that is, in thought or in discursive reason.

Sinful thoughts (logismoi) are hidden and very often lie in human subconscious ${ }^{26}$. Macarius of Egypt urged:

which there is not thought, they are not movements caused by will. There is no freedom of will; They are subject to a constraining necessity, according to which they move incessantly without change", Vasile cel Mare, Omilie la Psalmul 48. Părinți și Scriitori Bisericești. Vol. 17, București, EIBMBOR 1986, p. 319.

${ }^{20}$ Ware, Kallistos, Impărăția lăuntricăă, București, Christiana 1996 p. 85.

${ }^{21}$ For terminology and their division, see Špidlík, Tomáš, Spiritualitatea Răsăritului Creștin. Vol I. Manual sistematic, Sibiu, Deisis 2005, p. 285.

${ }_{22}$ There is, in a sense, a certain positivity of evil thoughts, in the sense that a man's consciousness that discovers wrong, false, or harmful thought can lead to the search for good things: "Tangalachi (Satan) of malice resembles cunning thoughts, but you value this work of yours in order to acquire unceasing prayer. To say to him, Good that you have brought these thoughts to me, because I have forgotten God and have spoken prayer", Paisie Aghioritul, Cuvinte duhovnicești, p. 154-155.

${ }^{23}$ Isihie Sinaitul, Către Teodul. Scurt cuvânt de folos sufletului şi mântuitor despre trezvie şi virtute, Sibiu, Tipografia Arhidiecezană 1948, p. 80.

24 Hierotheos Vlachos, Psihoterapia ortodoxă. Ştiinţa Sfinţilor Părinţi, Editura Învierea, Arhiepiscopia Timişoarei, 1998, p. 245.

25 Špidlík, Tomáš, Spiritualitatea Răsăritului Creștin. Vol I. Manual sistematic, Sibiu, Deisis 2005, p. 287.

${ }^{26}$ Evdokimov, Paul, Innoirea Spiritului, Târgoviște, Pandora, 1997. p. 194. 
"to suppress (the man) the forest of evil thoughts that surround him and to force himself to fulfill the commandments of God; not to let go of their thoughts, but to gather them from everywhere, to distinguish them from the evil ones. For the soul that is beneath sin is like a great forest on a mountain, or a brood in a river, or a bush of briers and thistles" 27.

Thoughts are fast, sharp, incisive and spontaneous. Basil the Great said that:

"the body, in order to commit an act, needs time, occasion, labor, aid, and other facilities; the mind, however, gives rise to thoughts in a moment and makes them without fatigue; and thoughts grow without hindrance and are appropriate for any time" 28 .

Evagrius Ponticus, also known as Evagrius the Solitary, points out that thoughts are insistent and powerful and often attack violently. Logismoi are "evil thoughts sneaking sensitive aspects into the soul" ${ }^{29}$.

Thoughts have a certain capacity to act in total autonomy ${ }^{30}$. The traditional concept of the Holy Fathers is that they are autonomous entities with a certain consistency and capable of penetrating by their own will. Moreover, once in the mind, they have the power to wander in different directions. From this point of view, thoughts are personified. Moreover, they are unpredictable, like a child:

"the mind is an unhindered child, a giddy and unloved child, who always wants to walk around and laugh" 31 .

Thoughts are changeable, covering a wide range. Evagrius Ponticus wrote that the are eight evil thoughts: gluttony, fornication, avarice, sorrow, discouragement, anger, vainglory, pride $^{32}$. Elder Paisios of the Holy Mountain stated that "the mind, in one moment, can take you to Heaven, and the next moment, if you do not remember, it will take you to hell" 33 . Thoughts are so intelligent and complex that they complicate the subject's mind. All these "brownian movements" in which the mind records lead to disorientation and mental exhaustion ${ }^{34}$. When interpreting the phrase "loosening the hidden" of Hesychius of Sinai, Emilianos Simonopetritus says that it is in fact a redeeming of the mind, by calming it, to find the meaning of life, and to respond to the most serious problems, such as health:

"How was the problem resolved? ... because your inner settlement has changed, your experience has changed ... Our problems are not unleashed because they are triggered by others and their surroundings" 35 .

\footnotetext{
${ }^{27}$ Macarie Egipteanul, Cele cincizeci de omilii duhovnicești, p. 122.

${ }^{28}$ Vasile cel Mare, Scrieri. Omilia a III-a la cuvintele: Ia aminte de tine insuti. Părinți și Scriitori Bisericești. Vol. 17, București, EIBMBOR, 1986, p. 366.

${ }^{29}$ Evagrie Ponticul, Capete despre deosebirea gândurilor. Filocalia I, Sibiu, Institutul de arte grafice "Dacia Traiana" 1947, Harisma, Bucureşti, p. 49.

${ }^{30}$ Bormolini, Guidalberto, I logismoi. La disciplina dei pensieri nei Padri del deserto, «Rivista di ascetica e mistica» 1 (2001) pp. 33-52.

${ }^{31}$ Paisie Aghioritul, Cuvinte duhovnicești, p. 175.

${ }^{32}$ Evagrie Ponticul, În luptă cu gândurile. Despre cele opt gânduri ale răutății și Replici împotriva lor, Sibiu, Deisis 2006.

${ }^{33}$ Paisie Aghioritul, Cuvinte duhovnicești, p. 171.

${ }^{34}$ Diadochus of Photicia says that the intellect is in a state of restlessness, marginalization, because only prayer gives it the possibility of an opening, Diadoh al Foticeii, Cuvânt ascetic, despre vieaţa morală, despre cunoştinţă şi despre dreapta socoteală duhovnicească, împărţit în 100 de capete. Filocalia I, Sibiu, Institutul de arte grafice "Dacia Traiana” 1947, Harisma, Bucureşti,, pp. 363-364.

${ }^{35}$ Emilianos Simonopetritul, Cuvânt despre trezvie. Tâlcuire la Sfântul Isihie, Arad, Editura Sf. Nectarie, 2014, P.40.
} 
How can it be explained, however, that people perceive a world created by God, according to the act of creation? Why are stimuli ruined when they reach the mind? The Holy Fathers say that there is nothing wrong in the world and that Satan works directly on the mind to create a misinterpretation of reality by changing the body. Maximus the Confessor says that temptations "change the organic state of the body, and give thoughts through it, whether with or without intemperance: angels, demons, air, and food. Angels, I say, change it by word (reason); devils by touch; air by combustion (metabolism); and alimentation, through the kinds of food and drink, by multiplying or shrinking them. There are also the changes that emerge through memory, hearing and sight, when the soul first suffers of sorrow or joy. Because of these the soul first changes the organic state of the body. The former ones, however, first change the organic state, and then instil thoughts into the $\operatorname{mind}^{36}$.

There are several stages of a sinful thought entering the heart. With a few small nuances $^{37}$, all the Holy Fathers who have spoken of this agree that sins start from thoughts and follow the following four-step process ${ }^{38}$ :

- Challenge of thought or suggestion. It is not just a temptation, but the presence of a strange thought;

- Interaction or dialogue with thought;

- Thinking or consent is the interest in the idea and the understanding of the mind, based on our freedom ${ }^{39}$;

- Transforming thought into action or committing sin.

\section{Method of Deliverence of the Mind}

First of all, to apply the method that helps in mental vigilance, a sincere desire for self-return is necessary. In everyday life the mind is mainly associated with senses and perceptions; for the spiritual struggle with evil thoughts to begin, the believer needs retrieval by eliminating the senses. Basil the Great says that:

\footnotetext{
${ }^{36}$ Maxim Mărturisitorul, Cuvânt Ascetic. Prin întrebări şi răspunsuri Fratele-Bătrânul. Filocalia. Vol II Apologeticum, 2005, p. 111.

37 "Among the discerning Fathers, distinctions are recognized between provocation, coupling, struggle, and the disease called passion, which is in the soul. These blessed Fathers say that provocation is a simple word or image encountered for the first time, which has entered into the heart. Coupling is conversation with what has been encountered, whether this be passionately or otherwise. Assent is the delighted yielding of the soul to what it has encountered. Captivity is a forcible and unwilling abduction of the heart, a permanent lingering with what we have encountered and which totally undermines the necessary order of our souls. By struggle they mean force equal to that which is leading the attack, and this force wins or loses according to the desires of the spirit. Passion, in their view, is properly something that lies hidden for a long time in the soul and by its very presence it takes on the character of a habit, until the soul of its own accord clings to it with affection", Ioan Scărarul, Scara raiului, Timișoara, Învierea 2013, p. 210-211.

38 Špidlík, Tomáš, Spiritualitatea Răsăritului Creștin. Vol I. Manual sistematic, Sibiu, Deisis 2005, pp. 289290; Hesychios describes this process : ,the provocation comes first, then our coupling with it, or the mingling of our thoughts with those of the wicked demons. Third comes our assent to the provocation, with both sets of intermingling thoughts contriving how to commit the sin in practice. Fourth comes the concrete action - that is, the sin itself If however, the intellect is attentive and watchful, and at once repulses the provocation by counter-attacking and gainsaying it and invoking the Lord Jesus, its consequences remain inoperative; for the devil, being a bodiless intellect, can deceive our souls only by means of fantasies and thoughts", Isihie Sinaitul, Către Teodul. Scurt cuvânt de folos sufletului şi mântuitor despre trezvie şi virtute. Filocalia. Vol 4., Sibiu, Tipografia Arhidiocezană 1948. p. 53-54.

${ }^{39}$ Lossky, Vladimir, Teologia mistică a Bisericii de Răsărit, București, Anastasia, p. 158.
} 
"when the mind is not scattered in the outer world, and the first senses are no more scattered in the world, it returns to itself and rises to the mind of God" 40 .

It is worth mentioning here that this rupturing of the world is not definitive and does not deny creation, because the purpose is to find God in every corner of the world and to be fascinated by the beauty of the world.

In a study on Hesychasm, Kallistos Ware states that there are three developments or understandings of the term, to send to the outer or inner silence of the monk. The first refers to the choice of the isolated human way of life that the first Christian monks wanted. The second, it also refers to a spatial dimension, that is, to the that each monk undertakes in his own cell. The third meaning is borne of the inner retreat of each monk. The present study is interested the second sense of the process, which associates the tradition of the wilderness with the vigilance of the mind. Thus, spiritual warmth or sobriety can be achieved in the quiet space that the monk has in his cell ${ }^{41}$. In that place there is a series of movements in the mind of the monk, far from a flattening of the mind, where silence is a context or a pretext for refining thoughts to virtue. The silence or space in which it enters is a dimension that rises and seeks essential answers, which in everyday life are covered by various worries:

\footnotetext{
"the monk that remains in the cell is like the chord of a finely tuned instrument. Hesychia keeps him in a state of vital tension, but without excessive anxiety. If it stays far out, the soul is humming and falling away" ${ }^{42}$.
}

As such it is very important that man is invited to introspection and cleansing of the mind. I could say that, based on Ware's line of reasoning, who asserts that there is a sect of the laity, every man who wants to gain a victory over evil thoughts needs an intimate space, a "prayer corner".

\section{The association between mind and prayer reveals virtues}

The importance of fighting evil thoughts is equal to the danger. The Tradition of the Christian East speaks of two ways of the mind fighting against thoughts. On the one hand, the mind can resist the evil concepts that overwhelm it. But:

"this method can lead to the opposite result, for, rejected by violence, thoughts tend to return with greater force. Whoever is not master of course is better to use the second method, which is indirect" 43 .

The second method is to point the mind to good things. The mission is not to immediately empty the mind, but to fill it with prayer and the call of God. The mind is thus an instrument through which the prayer of the heart can be reached, which goes beyond human understanding.

For this reason, the battle between the mind and constant prayer are like two sides of the same coin. From which it follows that they can not exist without each other and that they support each other. Both dynamics, a cathartic and sliding one that descends to the heart, and another ascetic and creative asceticism that comes from the heart to reshape the mind, are like two lungs of the same reality, that of spiritual life. From the heart, prayer also includes the mind, which becomes self-made. In other words, the cleansing of conscience and reason,

\footnotetext{
${ }^{40}$ Vasile cel Mare, Epistola II. Părinți și Scriitori Bisericești. Vol. 12, București, EIBMBOR 1988, p. 119.

${ }^{41}$ Ware, Kallistos, Impărăția lăuntrică B̆ București, Christiana, 1996 p. 79.

${ }^{42}$ Ware, Kallistos, Impărăția lăuntricăă, București, Christiana, 1996 p. 80.

${ }^{43}$ Ware, Kallistos, Impărăția lăuntrică , București, Christiana, 1996 p. 88.
} 
which in the Orthodox tradition has the term of ennoia, makes place or re-incarnates the intuitive faculty of mind, that is, nous $^{44}$ :

"the man whose prayer does not strive to say Jesus' Prayer, but without making an effort, speaks for and within itself. Even in sleep, he prays the Prayer, and when he awakens continues it" ${ }^{45}$.

"Hesychia means the passage from my prayer to the prayer of God that works in me", said Kallistos Ware ${ }^{46}$. But how is this prayer of the heart? Tomáš Špidlík says this is beyond words. It is neither imaginative nor conceptual, because "the multitude of ideas does not go hand in hand with the hesychia". The lack of any logical idea leads to a "genuine iconoclasm" ${ }^{47}$.

The method of defending evil thoughts recommended by the Holy Fathers is to combat them by quoting texts from the Holy Scripture. Evagrius Ponticus writes a true manual in this sense, called Antirreheticos ${ }^{48}$, in which he shares the eight thoughts of malice and offers remedies from the Bible to each. Each diabolical turn-over corresponds to quotations from Holy Scripture for the beautification of the mind. However, today's practice is rather little presence, much more used is the utterance of Jesus' Prayer. This is because, as Špidlík says:

"their learning was a considerable labor for a monk lacking in culture! But the practice simplified things. The invocation of Jesus became sufficient to banish all the demons, and Jesus' Prayer substitutes into mystery complicated classifications" ${ }^{49}$.

\section{CONCLUSIONS}

The first conclusion that emerges from the above is that human effort is needed for spiritual fulfillment. Although God has unlimited and mysterious powers, he demands from believer free will of and expression of the liberty, that he received in creation. This expression is a struggle that a faithful man must always hold. The second conclusion is that there is a reduction of religious experience to the mind dynamics. The Holy Fathers agree that the mind is the territory in which man's ability to do good or evil is played. Many of the Eastern Fathers quoted give to the mind a primordial, if not exclusive, role in generating sins. This reduction also results in the spiritual counsel they give, the instructions that come from their own experience. Man must focus on the mind and can do it with waking, consciousness, but especially with the struggle against thoughts. Another important conclusion is that this struggle, which tends to cancel or remove thoughts, is not confused with a simple cleansing of the mind, but with a healing of evil thoughts with the good ones. Good thoughts are those that contain God.

\footnotetext{
44 The difference between rational, discursive and intuitive minds is underlined in Špidlík, Tomáš, Spiritualitatea Răsăritului Creștin. Vol I. Manual sistematic, Sibiu, Deisis 2005, p.285.

${ }^{45}$ Paisie Aghioritul, Cuvinte duhovnicești, p. 159.

${ }^{46}$ Ware, Kallistos, Impărăția lăuntrică, București, Christiana, 1996 p. 86.

47 Špidlík, Tomáš, Spiritualitatea Răsăritului creștin. Vol. II. Rugăciunea, Sibiu, Deisis 1998, p. 320.

${ }^{48}$ Evagrie Ponticul, In luptă cu gândurile. Despre cele opt gânduri ale răutății și Replici împotriva lor, Sibiu, Deisis 2006.

49 Špidlík, Tomáš, Spiritualitatea Răsăritului creștin. Vol. II. Rugăciunea, Sibiu, Deisis 1998, p. 316.
} 


\section{BIBLIOGRAPHY:}

[1] Antonie cel Mare, Patericul Egiptean, Alba Iulia, Reîntregirea 2003

[2] Atanasie cel Mare, Cuvânt împotriva elinilor, Tratat despre întruparea Cuvântului, Trei cuvinte impotriva arienilor, București, IBMBOR 2010.

[3] Bormolini, Guidalberto, I logismoi. La disciplina dei pensieri nei Padri del deserto, «Rivista di ascetica e mistica» 1 (2001) pp. 33-52.

[4] Daniel de la Rarău, Gândurile bune în viaţa creştinului ortodox. Viaţa ca o prăznuire duhovnicească. Colecția „Rugul Aprins”, Panaghia 2013, p. ?.

[5] Diadoh al Foticeii, Cuvânt ascetic, despre vieaţa morală, despre cunoştinţă şi despre dreapta socoteală duhovnicească, împărţit în 100 de capete. Filocalia I, Sibiu, Institutul de arte grafice "Dacia Traiana" 1947, Harisma, Bucureşti.

[6] Emilianos Simonopetritul, Cuvânt despre trezvie. Tâlcuire la Sfântul Isihie, Arad, Editura Sf. Nectarie, 2014.

[7] Evagrie Ponticul, Capete despre deosebirea gândurilor. Filocalia I, Sibiu, Institutul de arte grafice "Dacia Traiana", Harisma, Bucureşti 1947.

[8] Evagrie Ponticul, În luptă cu gândurile. Despre cele opt gânduri ale răutății și Replici împotriva lor, Sibiu, Deisis 2006.

[9] Evdokimov, Paul, Înnoirea Spiritului, Târgoviște, Pandora, 1997.

[10] Hausherr, Irénée, Paternitatea şi îndrumarea duhovnicească în Răsăritul creştin, Sibiu, Deisi 1999.

[11] Hierotheos Vlachos, Psihoterapia ortodoxă. Ştiinţa Sfinţilor Părinţi, Editura Învierea, Arhiepiscopia Timişoarei, 1998.

[12] Ioan Damaschinul, Dogmatica, Bucureşti, Apolgeticum 2004.

[13] Ioan Scărarul, Scara raiului, Timișoara, Învierea 2013.

[14] Isihie Sinaitul, Către Teodul. Scurt cuvânt de folos sufletului şi mântuitor despre trezvie şi virtute. Filocalia. Vol 4., Sibiu, Tipografia Arhidiecezană 1948.

[15] Lossky, Vladimir, Teologia mistică a Bisericii de Răsărit, București, Anastasia.

[16] Macarie Egipteanul, Cele cincizeci de omilii duhovnicești. Părinții și Scriitori Bisericești. Vol. 34, București, EIBMBOR 1992.

[17] Macarie Egipteanul, Cele cincizeci de omilii duhovnicești. Părinți și Scriitori Bisericești. Vol. 34, București, EIBMBOR 1992

[18] Marcu Ascetul, Filocalia. Vol. I, Sibiu, Editura Institutul de Arte Grafice „Dacia Traiană” 1947.

[19] Maxim Mărturisitorul, Cuvânt Ascetic. Prin întrebări şi răspunsuri Fratele-Bătrânul. Filocalia. Vol II, Apologeticum, 2005.

[20] Maxim Mărturisitorul, Disputa Sfântului Maxim cu Pyrhus. Părinți și Scriitori Bisericești. Vol. 81, București, EIBMBOR 1990.

[21] Paisie Aghioritul, Cuvinte duhovnicești. Vol IV. Despre rugăciune, București, Evanghelismos 2013.

[22] Piovano, Adalberto, Vigilanza e attenzione su di sé: il versante monastico, Tredimensioni 4(2007) 275-282.

[23] Simeon Noul Teolog, Metoda sfintei rugăciuni şi atențiuni. Filocalia. Vol. 8, București, EIBMBOR 1979.

[24] Špidlík, Tomáš, Spiritualitatea Răsăritului Creștin. Vol I. Manual sistematic, Sibiu, Deisis 2005.

[25] Špidlík, Tomáš, Spiritualitatea Răsăritului creștin. Vol. II. Rugăciunea, Sibiu, Deisis 1998.

[26] Stăniloaie, Dumitru, Ascetica și mistica Bisericii Ortodoxe, București, EIBMBOR 2002.

[27] Vasile cel Mare, Epistola 233. Părinți și Scriitori Bisericești. Vol. 12, București, EIBMBOR 1988.

[28] Vasile cel Mare, Omilie la Psalmul 48. Părinți și Scriitori Bisericești. Vol. 17, București, EIBMBOR 1986.

[29] Ware, Kallistos, Împărăția lăuntrică, București, București, Christiana 1996. 